\title{
46. THE COMPRESSIONAL WAVE VELOCITIES OF SOME DSDP LEG 34 BASALTS: A BRIEF REPORT
}

\author{
Edward Schreiber, Department of Earth and Environment Sciences, Queens College \\ C.U.N.Y., Flushing, N.Y., and Lamont-Doherty Geological Observatory, Palisades, New York
}

\section{INTRODUCTION}

Laboratory measurement of sonic wave propagation performed on rocks recovered from the sea floor is one means of correlating seismic refraction models of the oceanic crust with petrologic models. Consequently, the compressional wave velocities have been determined for eight samples of basalt recovered during DSDP Leg 34. Six of the samples are from Hole 319A near the spreading axis of the East Pacific Rise, and two samples are from Site 321 near the Peru-Chile trench.

Measurements were performed on air-dried, jacketed samples using the techniques of sample preparation and velocity measurement described earlier (Schreiber et al., 1972). Velocities are reported up to a pressure of $4 \mathrm{kbar}$ which exceeds the calculated confining pressure at the base of layer 3 . The results are shown in Table 1 .

\section{RESULTS}

Visual megascopic examination of the samples from Hole 319A indicates alteration which decreases with depth of the core. Grain size first increases and then decreases suggesting that the samples come from a discrete flow unit. The samples from Site 321, although from what should be older crust, appear to be no more altered than that from the upper part of the core in Hole 319A. The detailed descriptions of the lithology and mineralogy of the basalts recovered at these sites appears in Chapters 2 and 4 of this volume.

There is a rather small range of variation in density for all the samples examined, and this is reflected in the narrow range of velocities reported (Table 1). At a pressure of $1.5 \mathrm{kbar}$, the effect of cracks (which have a large effect in reducing the velocity) is essentially eliminated. The exceptions are two samples (319A-2-2,
18-21 $\mathrm{cm}$ and $319 \mathrm{~A}-2-2,28-32 \mathrm{~cm}$ ) which also appear to be more strongly altered.

The velocities of the two samples from Site 321 are not very different from the samples in the upper part of the core recovered from Hole 319A and also do not appear to be altered to any greater degree. This is a rather interesting occurrence since the basalt at Site 321 underlies older sediment, where presumably older crust was sampled. Radiometric dating of these samples would resolve the question as to whether these are indeed older basalts, but that the extent of alteration with time has been truncated, or whether younger igneous material was recovered at Site 321 indicating off-ridge igneous activity. The velocities for basalts from both Hole 319A and Site 321 are greater than the bulk of seismic refraction velocities reported for layer 2 in the Pacific but fall within the spread of the reported velocities (Shor et al., 1970). The values reported here are consistent with the seismic refraction results for the Nazca plate.

\section{ACKNOWLEDGMENT}

The author expresses his appreciation to Dr. P.J. Fox for his suggestions and comments.

\section{REFERENCES}

Schreiber, E., Fox, P.J., and Peterson, J.J., 1972. Compressional sound velocities in semi-indurated sediments and basalts from DSDP Leg 11. In Hollister, C.D. and Ewing, J.I., et al., Initial Reports of the Deep Sea Drilling Project, Volume 11: Washington (U.S. Government Printing Office), p. 723-727.

Shor, G.G., Menard, H.W., and Raitt, R.W., 1970. Structure of the Pacific basin. In Maxwell, A.E. (Ed.), The sea, Vol. 4, part 2: New York (John Wiley and Sons), p. 2-27.

TABLE 1

Compressional Wave Velocities and Densities for Basalts from Leg 34 (Velocity in $\mathrm{km} / \mathrm{sec})^{\mathrm{a}}$

\begin{tabular}{l|ccccccc|c}
\hline \multirow{2}{*}{$\begin{array}{c}\text { Sample } \\
\text { (Interval in cm) }\end{array}$} & 0.001 & 0.5 & 1.0 & 1.5 & 2.0 & 3.0 & 4.0 & Density \\
\cline { 2 - 7 } & $\left(\mathrm{gm} / \mathrm{cm}^{3}\right.$ ) \\
\hline $319 \mathrm{~A}-2-2,18-21$ & 5.00 & 5.43 & 5.54 & 5.60 & 5.63 & 5.69 & 5.75 & 2.85 \\
$319 \mathrm{~A}-2-2,28-32$ & 5.58 & 5.74 & 5.83 & 5.88 & 5.92 & 5.97 & 6.02 & 2.92 \\
$319 \mathrm{~A}-3-4,72-76$ & 5.47 & 5.95 & 6.02 & 6.05 & 6.08 & 6.11 & 6.13 & 2.93 \\
$319 \mathrm{~A}-3-4,79-82$ & 5.72 & 5.96 & 6.03 & 6.06 & 6.09 & 6.12 & 6.14 & 2.92 \\
$319 \mathrm{~A}-5-1,97-100$ & 5.76 & 6.02 & 6.07 & 6.10 & 6.11 & 6.13 & 6.15 & 2.92 \\
$319 \mathrm{~A}-5-1,100-109$ & 5.79 & 5.99 & 6.00 & 6.01 & 6.02 & 6.06 & 6.08 & 2.90 \\
$321-14-2,20-26$ & 5.60 & 5.88 & 5.91 & 5.92 & 5.93 & 5.94 & 5.95 & 2.85 \\
$321-14-2,25-28$ & 5.47 & 5.85 & 5.87 & 5.88 & 5.89 & 5.90 & 5.91 & 2.82 \\
\hline
\end{tabular}

${ }^{\mathrm{a}}$ Precision of above measurements is $1 \%$. 